\title{
Winter $\mathrm{CO}_{2}$ fluxes in a boreal forest
}

\author{
G. C. Winston, E. T. Sundquist \\ U.S. Geological Survey, Woods Hole, Massachusetts
}

B. B. Stephens

Scripps Institution of Oceanography, University of California, San Diego, La Jolla

\author{
S. E. Trumbore \\ Earth System Science, University of California, Irvine
}

\begin{abstract}
We measured soil respiration during two winters in three different ecotypes of the BOREAS northern study area. The production of $\mathrm{CO}_{2}$ was continuous throughout the winter and, when totaled for the winter of 1994-1995, was equivalent to the release of $\sim 40-55 \mathrm{~g} \mathrm{C}^{2} \mathrm{~m}^{2}$ from the soil surface. As soils cooled in the early winter, the $\mathrm{CO}_{2}$ production rate decreased in a manner that appeared to be exponentially related to shallow soil temperatures. This exponential relationship was not observed when soils began to warm, possibly indicating that there may be additional or different processes responsible for increased $\mathrm{CO}_{2}$ production during winter warming events. We also measured $\mathrm{CO}_{2}$ concentrations in soil gas and the $\Delta^{14} \mathrm{C}$ of the soil $\mathrm{CO}_{2}$. These measurements show that the $\mathrm{CO}_{2}$ produced in winter is not simply the return to the atmosphere of the carbon fixed during the previous growing season. We suggest that the wintertime production of $\mathrm{CO}_{2}$ originates, at least in part, from the decomposition of old organic carbon stored at depth in the soil.
\end{abstract}

\section{Introduction}

A major focus of the Boreal Ecosystem-Atmesphere Study (BOREAS) is to understand carbon exchange between the boreal forests and the atmosphere. Winter production of $\mathrm{CO}_{2}$ is especially critical in understanding the annual cycling of carbon in these ecosystems [Frolking et al., 1996] since it is known to return to the atmosphere a significant portion of the carbon fixed during the growing season [Goulden et al., this issue]. Soil respiration, a process that includes contributions from plants and microbial decomposition of litter and organic matter in soil, is a major contributor to winter $\mathrm{CO}_{2}$ production. Winter soil respiration has been estimated to contribute $20 \%$ or more of the annual amount of $\mathrm{CO}_{2}$ evolved from the soil in alpine, arctic, and temperate ecosystems [Sommerfeld et al., 1993; Zimov et al., 1993; Sommerfeld et al., 1991; Dörr and Münich, 1987; Coxson and Parkinson, 1987a, b; Solomon and Cerling, 1987; Edwards, 1975; Phillipson et al., 1975; Havas and Mäenpää, 1972; Woodwell and Dykeman, 1966], yet little is known about winter emissions from boreal forests.

During the winters of 1993-1994 and 1994-1995 we measured $\mathrm{CO}_{2}$ fluxes at the snowpack surface, soil temperatures, soil $\mathrm{CO}_{2}$ concentrations, apparent soil dielectric constants, and $\Delta^{14} \mathrm{C}$ of soil $\mathrm{CO}_{2}$. Our intention was to relate the measured $\mathrm{CO}_{2}$ fluxes to subsurface processes and to determine the magnitude and seasonal trends of those fluxes. Measurements were made during the periods November 14-20, 1993; January 20 to February 27, 1994; April 20-28, 1994; October 23 to November 7, 1994; November 30 to December 8, 1994; January 14 to February 13, 1995; and March 16 to April 24, 1995. Some data

Copyright 1997 by the American Geophysical Union.

Paper number 97JD01115.

0148-0227/97/97JD-01115\$09.00 from the winter of 1993-1994 have been reported previously [Winston et al., 1995].

In this paper we relate seasonal and interannual trends in soil temperature and moisture to variations in soil respiration and soil gas $\mathrm{CO}_{2}$ concentrations. We examine the importance of $\mathrm{CO}_{2}$ production and transport in controlling soil gas $\mathrm{CO}_{2}$ concentrations and fluxes. We use our soil respiration data to estimate the cumulative seasonal respiration. We report significant depletion of ${ }^{14} \mathrm{C}$ in soil gas $\mathrm{CO}_{2}$ and suggest that the $\mathrm{CO}_{2}$ fluxes observed throughout the winter must be supported by ongoing $\mathrm{CO}_{2}$ production originating, at least in part, from the decomposition of old organic carbon stored at depth in the soil.

\section{Background}

Studies of winter forest floor respiration have focused on the decomposition of litter and soil organic matter (reviewed in part by Taylor and Jones [1990]). Continuous $\mathrm{CO}_{2}$ respiration by bacterial and fungal communities has been observed throughout the winter [Vuorinen and Kurkela, 1993; Zimov et al., 1993; Carreiro and Koske, 1992; Coxson and Parkinson, 1987a]. This microbiological activity appears to be related to temperature [Lloyd and Taylor, 1994] and to the availability of free water [Brooks et al., 1996; Zimov et al., 1993; Flanagan and Veum, 1974].

Studies of microbial responses to cold temperatures report that below temperatures ranging from $-7.5^{\circ}$ to $-5^{\circ} \mathrm{C}$, microbiological respiration is undetectable [Schimel et al., 1995; Flanagan and Scarborough, 1972; Flanagan and Veum, 1974; Benoit et al., 1972; Flanagan and Bunnell, 1980; Coxson and Parkinson, 1987a]. Free water persists in a wide variety of soil types at temperatures as low as $-5^{\circ} \mathrm{C}$ and perhaps at even colder temperatures [Patterson and Smith, 1981] depending on soil type. It is not clear, however, whether the soil moisture 
levels observed at these temperatures are high enough to support microbiological activity.

Snow can cover the ground in boreal ecosystems for more than half the year. Several methods have been used to measure or estimate $\mathrm{CO}_{2}$ fluxes through snow. Direct measurements have been made using chambers on the snow surface [Winston et al., 1995; Hardy et al., 1995; Winston et al., 1992] and eddy correlation techniques [Goulden et al., this issue]. Fluxes have also been calculated by applying Fick's first law of diffusion to measured concentration gradients and estimated diffusion coefficients in the snowpack [Brooks et al., 1996; Sommerfeld et al., 1993; Zimov et al., 1993; Sommerfeld et al., 1991; Solomon and Cerling, 1987; Sommerfeld et al., 1996]. The accuracy of these methods is very difficult to assess [Sommerfeld et al., 1996].

Snowpack characteristics evolve throughout the season and can exert considerable influence on the transport of gases. These characteristics include snow density variations induced by compaction (particularly, in forests, compaction caused by snow sloughed from trees), ice lens formation [Winston et al., 1995; Hardy et al., 1995], and channels created by ablation around tree stems and the movement of trees by wind [Winston et al., 1995; Winston et al., 1992]. Other variations in the morphology of the snowpack, such as the formation of depth hoar, may be important as well [Sturm and Johnson, 1991; Coyne and Kelley, 1974]. Wind can influence gas transport by ventilating the snowpack [Albert and Hardy, 1995] or inducing pressure fluctuations [Massman et al., 1995]. Changes in $\mathrm{CO}_{2}$ fluxes measured through snow may be attributed both to changes in the gas transport properties of the snow and to changes in soil $\mathrm{CO}_{2}$ production.

\section{Methods \\ Site Preparation}

In August 1993 we established three sites in three forest ecotypes on sandy and clay soils in the BOREAS northern study area (NSA) near Thompson, Manitoba. The predominant species of the three ecotypes were old black spruce (OBS) (picea mariana, on predominantly clay soils), young jack pine (YJP) (pinus banksiana, on predominantly sandy soils), and old jack pine (OJP) (on predominantly sandy soils). Soil pits were dug near the three eddy correlation flux towers at OBS (the only NSA tower running in winter), YJP, and OJP. Nine more sites were established in August 1994, transecting a range of soil moisture and canopy closure conditions within the footprint of the OBS eddy correlation flux tower. Each pit was described and sampled for organic carbon and ${ }^{14} \mathrm{C}$ content [O'Neill et al., 1994a, b; Trumbore and Harden, this issue]. Temperature, time domain reflectometry (TDR), and soil gas probes (described in more detail below) were installed horizontally at different depths in the pit wall before backfilling. Only temperature and gas probes were installed in the nine OBS pits dug in 1994.

\section{Soil Temperatures and Apparent Dielectric Constants}

We measured soil temperatures using calibrated thermistors (thermocouples at OJP) which were inserted horizontally in the vertical face of each soil pit before backfilling. Apparent dielectric constants were measured using TDR. We assembled TDR probes consisting of two prongs $30 \mathrm{~cm}$ long spaced $2 \mathrm{~cm}$ apart (purchased from Campbell Scientific, Logan, Utah; use of brand names in this paper does not imply endorsement by the U.S. Geological Survey). These probes were inserted horizontally to their full length into the soil pit face before backfilling. Apparent dielectric constants were obtained using the Campbell Scientific TDR system which employs the Tektronix 1502B cable tester (Beaverton, Oregon).

\section{Soil Gas $\mathrm{CO}_{2}$ Concentrations}

Soil gas probes were made from $60 \mathrm{~cm}$ lengths of $1 / 8$-inch stainless steel tubing which were crimped at the tips and perforated over a $5 \mathrm{~cm}$ length from the tip. These probes were inserted horizontally to their full length at various depths into the face of each soil pit. Nylon tubing, connected to each gas probe with a Swagelok union, ran from the probes to above the snow surface. The nylon tubing was capped with Swagelok caps between sampling. Samples were drawn directly into specially designed stainless steel containers [Winston et al., 1995] which were tested to hold samples for over 24 hours at $-35^{\circ} \mathrm{C}$ with no measurable change. We analyzed the samples for $\mathrm{CO}_{2}$ (without drying) within 24 hours of sampling using an infrared gas analyzer (IRGA) method similar to the method of Davidson and Trumbore [1995].

\section{$\mathrm{CO}_{2}$ Fluxes}

We used a "floating" closed-chamber method to measure the $\mathrm{CO}_{2}$ efflux at the snowpack surface (described in more detail by Winston et al. [1995]). The air within the chamber was circulated continuously through an IRGA (model LI-6200, LICOR Inc., Lincoln, Nebraska) mounted within an insulated box. This configuration kept analyzer temperatures relatively constant during each flux measurement and maintained the proper detector temperature. We calibrated the IRGA daily at ambient air temperatures with a primary standard mixture of $\mathrm{CO}_{2}$ in air (705 ppmv $\pm 1 \%$ ). $\mathrm{CO}_{2}$ concentrations were recorded in the chamber every $20 \mathrm{~s}$. Fluxes were calculated from the slopes of the concentration versus time curves, the system volume, and the surface area covered by the chamber. Molar fluxes were based on concentrations adjusted for temperature and pressure; no correction for water vapor was necessary because the circulated air was not dried.

Closed chambers are not an accurate method for measuring gas transport driven by advective processes, because the chamber itself disrupts advection across and through the snow surface. Closed chambers work best when vertical diffusion is the dominant means of transport. We observed an association between high winds and decreased chamber fluxes which we believe was caused by advective ventilation of the snowpack. When a chamber is placed on such a ventilated snowpack, concentrations within the snowpack cannot be expected to support a representative flux by diffusion. Measurements reported here were obtained during days when there was little or no wind, minimizing the extent of advective transport.

Under diffusive transport conditions, the chamber perturbs the natural $\mathrm{CO}_{2}$ flux by increasing the concentration of $\mathrm{CO}_{2}$ at the snow surface relative to the true ambient concentration. This perturbation reduces the diffusion of $\mathrm{CO}_{2}$ out of the snow. The chamber system was modeled to assess the effect of this perturbation on the accuracy of our flux measurements [Stephens and Sundquist, 1995, B. B. Stephens and E. T. Sundquist, manuscript in preparation, 1997]. According to the model results the perturbation artifact is enhanced when measuring flux through a snowpack more than through soil because of the relatively high porosity of snow. The modeling results suggest that for snow depths and diffusivities similar to those 
encountered in this work, our measurements yield flux values that are approximately $75-85 \%$ of the undisturbed local diffusive fluxes.

To avoid disturbing the snow during sampling, we performed our flux measurements from catwalks suspended over the snow and supported by wooden frames enclosing $10 \mathrm{ft} \times 10 \mathrm{ft}$ areas at each site, or by using a pole to extend the chamber at least $2.5 \mathrm{~m}$ from where we stood. By these methods the snowpack could be preserved for the entire season, and the same sites could be sampled repeatedly with minimal disturbance.

\section{Carbon 14 Measurements}

Samples of soil air for analysis of $\mathrm{C}$ isotopes in $\mathrm{CO}_{2}$ were collected from soil gas probes into one to three preevacuated, electropolished, $500 \mathrm{cc}$ aluminum cans. Carbon dioxide was concentrated from (dried) air in the cans by sorption onto $5 \AA$ molecular sieve at room temperatures [Bauer et al., 1992]. Purified $\mathrm{CO}_{2}$ released by heating the molecular sieve to $450^{\circ} \mathrm{C}$ was split for analysis of ${ }^{14} \mathrm{C}$ by accelerator mass spectrometry (AMS) and ${ }^{13} \mathrm{C}$ by stable isotope mass spectrometry. ${ }^{14} \mathrm{C}$ analyses were made at the Lawrence Livermore Center for AMS [Southon et al., 1992]. Results for $C$ isotope analyses are reported as $\Delta^{14} \mathrm{C}$ and $\delta^{13} \mathrm{C}$, where $\Delta^{14} \mathrm{C}=1000^{*}(R$ $\left.\left(0.95^{*} R_{\text {oxalic aciu }}\right)-1\right)$ and $\delta^{13} \mathrm{C}=1000^{*}\left(R_{\text {sample } 13} / R_{\text {stdil } 13}-\right.$ 1). $\left(R_{\text {rample } 14}\right.$ is the ${ }^{14} \mathrm{C} /{ }^{12} \mathrm{C}$ ratio of the sample corrected for fractionation effects to a $\delta^{13} \mathrm{C}$ value of -25 per mil; $R_{\text {oxalıc acid }}$ is the ${ }^{14} \mathrm{C} /{ }^{12} \mathrm{C}$ ratio of oxalic acid slandard decay-corrected to the year 1950 and fractionation-corrected to a $\delta^{13} \mathrm{C}$ value of -19 per mil; $R$ is the ${ }^{13} \mathrm{C} /{ }^{12} \mathrm{C}$ ratio of the sample; and $R_{\text {std } 13}$ is the ${ }^{1.3} \mathrm{C} /{ }^{12} \mathrm{C}$ ratio of the Pee Dee Belemnite standard.). Measured $\delta^{1.3} \mathrm{C}$ values were used in the calculation of $\Delta^{14} \mathrm{C}$.

\section{Results and Discussion}

\section{Soil Temperatures}

Soil temperatures obtained from each of the eddy diffusion flux tower sites during the winters of 1993-1994 and 1994-1995 are shown in Figure 1. The coldest soil temperatures were measured during the winter of 1993-1994. Soil temperature minima occurred that year in February and, at most depths, were below the minimum temperature (about $-5^{\circ}$ to $-7^{\circ} \mathrm{C}$ ) previously observed for measurable respiration by microorganisms. In the winter of 1994-1995 the lowest measured soil temperatures were $3^{\circ}$ to $8^{\circ} \mathrm{C}$ higher than those of the previous winter and remained, at many depths (Figure 1), above the minimum temperature observed for measurable respiration.

Between January and February 1995 we observed a transient midwinter warming in the soils at the OJP and YJP sites. (The shallowest probe at YJP in February does not show the warming, probably because of a response to air temperatures which were beginning to drop again when we sampled this site.) The increase in soil temperatures provided an opportunity to examine the short-term response of $\mathrm{CO}_{2}$ fluxes to warming. This event was not observed at the OBS site, possibly because of the insulating effect of the thick moss layers present at that site.

\section{Apparent Soil Dielectric Constants}

Apparent soil dielectric constants $\left(\varepsilon_{\text {app }}\right.$ ) are shown (for 1994-1995) in Figure 2. At the sites on sandy soils (OJP and YJP) we observed low $\varepsilon_{\text {app }}$ values that dropped upon pronounced winter cooling (between October and January) and then either continued a slow decline or remained stable until the spring thaw. The $\varepsilon_{\mathrm{app}}$ values, obtained when soil temper-

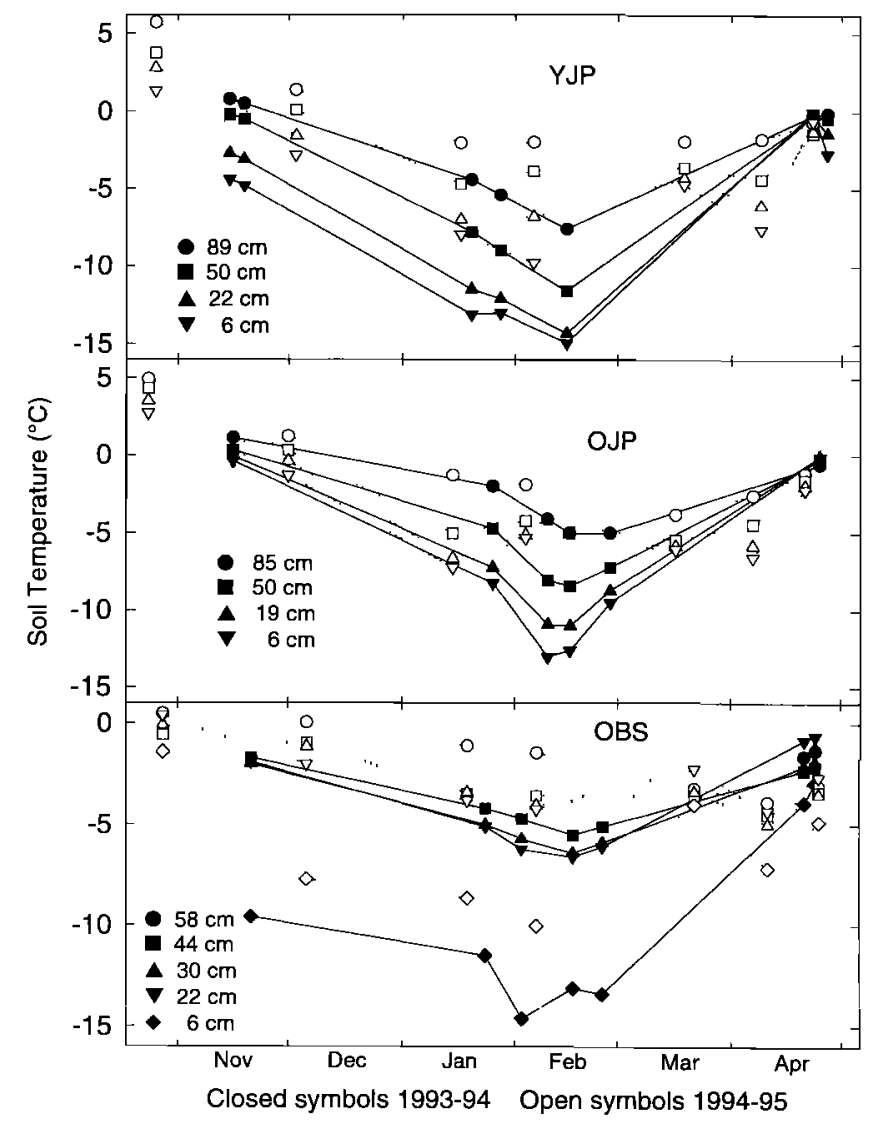

Figure 1. Soil temperatures measured during the winters of 1993-1994 and 1994-1995 at the young jack pine (YJP), old jack pine (OJP), and old black spruce (OBS) tower sites in the BOREAS northern study area. Closed symbols are for 19931994 and open symbols are for 1994-1995. Depths are relative to the soil surface.

atures were at their minima in sandy soils, were approximately 10\% higher during the winter of 1993-1994 than during 19941995.

We observed higher $\varepsilon_{\mathrm{dpp}}$ values in the mineral horizons in clay soils (OBS) than in sandy soils. At the OBS site, two of our probes (at 12 and $22 \mathrm{~cm}$ depth) were situated in layers of decomposing mosses. The $\varepsilon_{\text {app }}$ values, obtained from those probes in 1994-1995, were much lower and more stable than those in mineral soil $(31,42$, and $58 \mathrm{~cm})$ at this location.

An empirical relationship between the free (liquid) water content and the $\varepsilon_{\text {app }}$ has been developed for mineral soils [Topp et al., 1980] and shown to be reasonably valid for various types of mineral soils containing both frozen and free water [Patterson and Smith, 1981]. This relationship is defined by the equation

$$
\begin{aligned}
\Theta_{f w}= & 4.3 \times 10^{-6}\left(\varepsilon_{\mathrm{app}}\right)^{3}-5.5 \times 10^{-4}\left(\varepsilon_{\mathrm{app}}\right)^{2}+2.92 \\
& \times 10^{-2} \varepsilon_{\mathrm{app}}-5.3 \times 10^{-2}
\end{aligned}
$$

where $\Theta_{f w}$ is the volumetric free unfrozen water content and $\varepsilon_{\text {app }}$ is the apparent dielectric constant of the soil matrix. Using this equation, we calculate that the sandy soils (OJP and YJP) displayed very low volumetric water contents (1-5\%) even before freezing occurred. When these soils reached their minimum temperatures, the amount of calculated free unbound water was extremely low $(0-1 \%)$. The accuracy of these mois- 


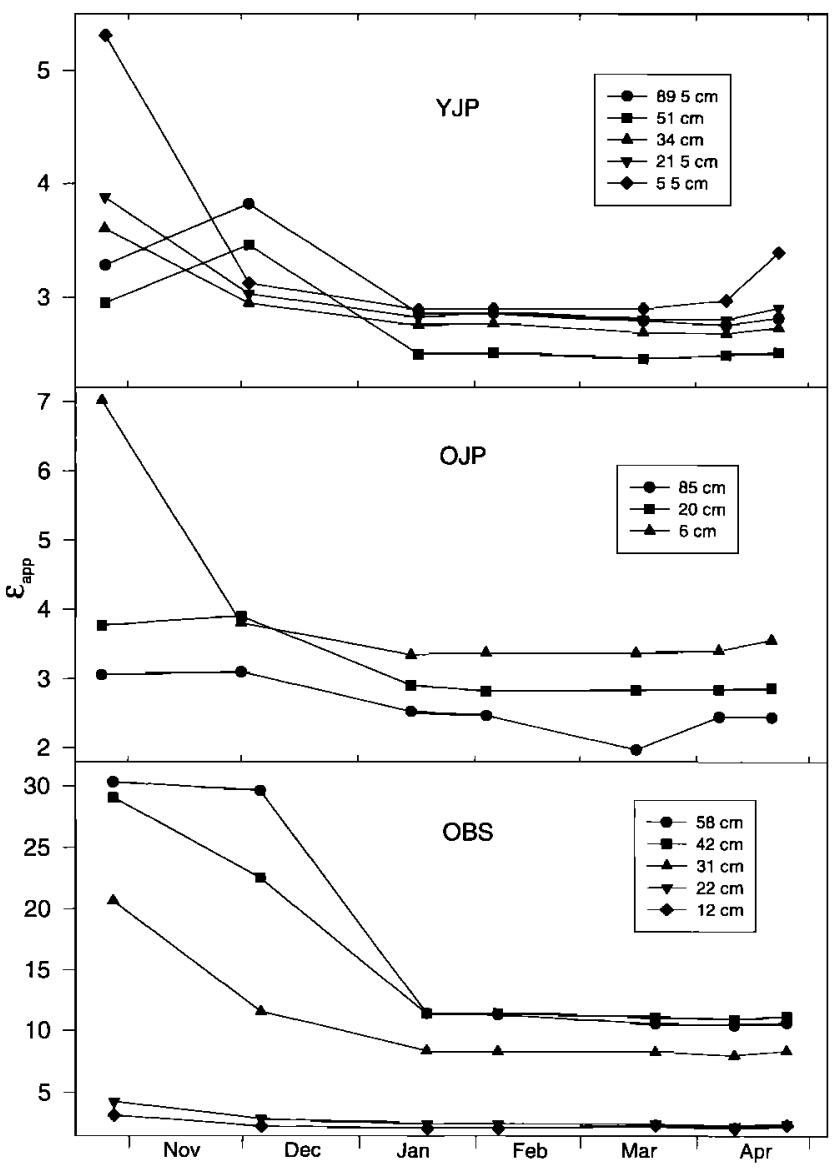

Figure 2. Apparent soil dielectric constants measured during the winter of 1994-1995. Sites and depths are as in Figure 1.

ture calculations is subject to uncertainty due to the lack of direct calibration in the observed soils. However, relative differences in $\varepsilon_{\text {app }}$ should reflect real differences in soil moisture. We believe that the higher apparent dielectric constants determined at these sites in 1993-1994 indicate that these soils contained more free unbound water during that winter than the 1994-1995 moisture levels reflected in the data shown in Figure 2.

Similarly, our observation of higher $\varepsilon_{\mathrm{app}}$ values in the clay soils (OBS) suggests higher water contents. Equation (1) suggests values of $30-40 \%$ soil moisture in the mineral horizons before the onset of pronounced winter cooling and values of $15-20 \%$ even when soil temperatures were at their minimum. Thus although the amount of free water appears to be reduced by freezing, equation (1) indicates that free unbound water remains in these soils throughout the winter. Free unbound water has previously been shown to exist in mineral soils at temperatures far below $0^{\circ} \mathrm{C}$ and is believed to be found in films coating clay minerals and in soil micropores [Patterson and Smith, 1981].

\section{Soil $\mathrm{CO}_{2}$ Concentration Gradients}

Soil $\mathrm{CO}_{2}$ concentrations are plotted against soil depth in Figure 3. The profiles show concentrations increasing with depth except for some measurements in the fall and in the spring. The increases in concentration with depth were maintained during both winters (1993-1994 data are reported by Winston et al. [1995]). The slopes of the concentration versus

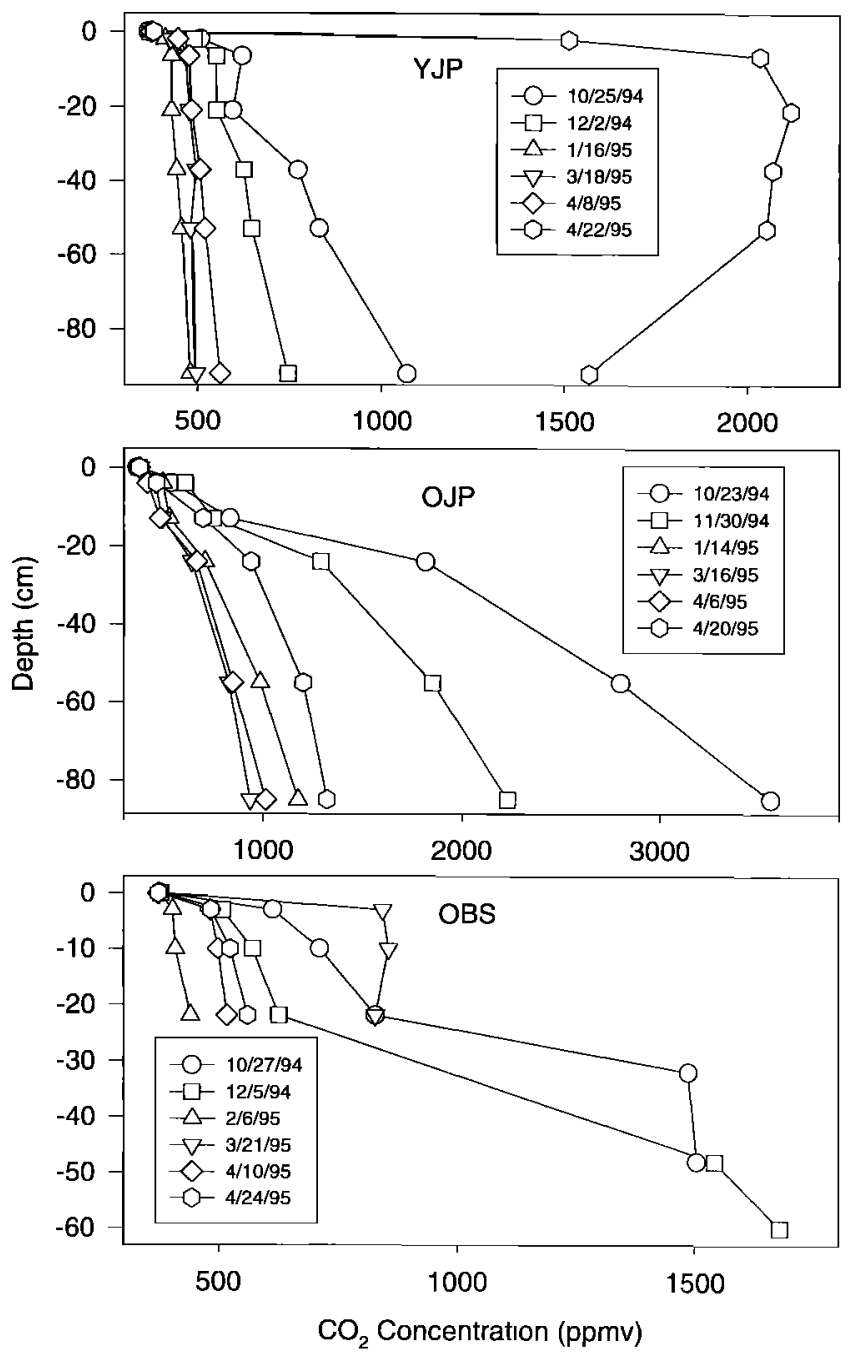

Figure 3. Carbon dioxide concentration versus depth profiles for soils during the winter of 1994-1995. Sites are as described for Figure 1. Depths are relative to the soil surface. Concentrations reported for zero depth are ambient atmospheric $\mathrm{CO}_{2}$ concentrations at a height of $1.5 \mathrm{~m}$ and not the concentrations at the soil-snow interface.

depth gradients tended to decrease as soil temperatures became colder. In some cases we observed that as soil temperatures dropped, the deepest concentrations remained at relatively high levels (OJP in 1993-1994 [Winston et al., 1995]) or increased (OBS in 1994-1995, site 6A in Figure 4), while simultaneously concentrations at shallower depths decreased. In the spring of both years we saw a conspicuous reversal in the downward increasing gradients at the YJP site.

Three factors are most likely to have controlled these changes in soil $\mathrm{CO}_{2}$ concentration gradıents: (1) changes in the distribution of $\mathrm{CO}_{2}$ production within the soil, caused by changes in the distribution of soil moisture, temperature, and consequently the activity of plants and/or microbes; (2) changes in the diffusivity of $\mathrm{CO}_{2}$ within the soil, caused by water freezing, thawing, or migrating into different horizons; (3) changes in the diffusion of $\mathrm{CO}_{2}$ above the soil surface, caused by changes in the gas transport properties of the snowpack.

Changes in the vertical distribution of $\mathrm{CO}_{2}$ production are 


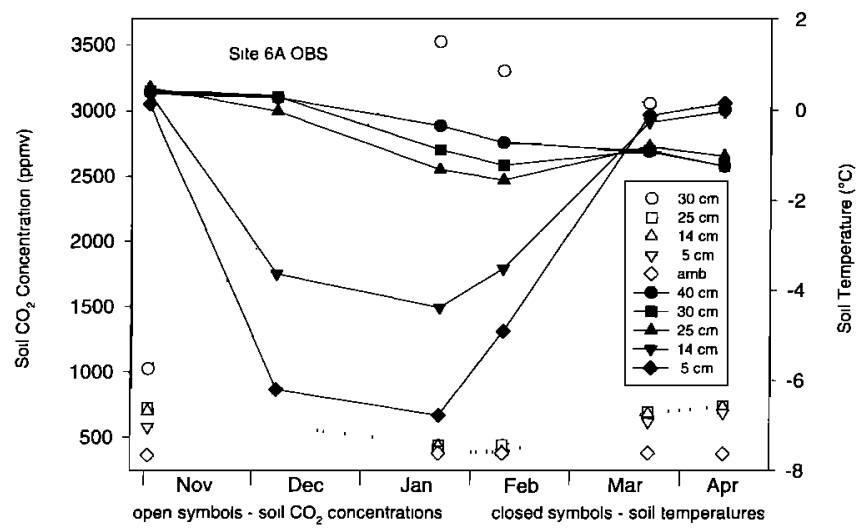

Figure 4. Soil temperatures (solid lines) and $\mathrm{CO}_{2}$ concentrations (dashed lines) for OBS site 6A in 1994-1995. Depths are relative to the soil surface.

probably responsible for the general seasonal trends of the concentration gradients. Production would be expected to decrease as the wintertime cold penetrates the soil. This decrease in production can explain the decrease in concentration gradients as the soil cools. However, the maintenance of positivedownward concentration gradients indicates the persistence of deep $\mathrm{CO}_{2}$ sources, presumably supported by relatively warm deep soil temperatures. In the spring, increased $\mathrm{CO}_{2}$ production associated with warming at shallow depths is likely the cause of the reversal in downward increasing gradients observed at YJP.

We believe that changes in soil diffusivities affected the soil $\mathrm{CO}_{2}$ distributions at the OBS site in 1994-1995 (Figure 4) and possibly at the OJP site in 1993-1994 [Winston et al., 1995]. We suggest that water freezing into the soil pore space at these sites may have lowered the effective diffusivity of $\mathrm{CO}_{2}$ by decreasing the soil porosity and otherwise increasing barriers to gas transport. This phenomenon could explain the increase in $\mathrm{CO}_{2}$ concentrations at depth in the clay soils at OBS, while temperatures continued to decrease (Figure 4). At OJP this effect may have occurred when there was higher soil moisture available to freeze into the pore space (1993-1994), whereas it was not apparent when the soil moisture was lower (19941995).

We found no evidence for changes in soil $\mathrm{CO}_{2}$ profiles caused by changes in the transport properties of the overlying snowpack. Hardy et al. [1995] discovered some of the highest snow permeabilities on record for the snow at these sites during the winter of 1993-1994. The snowpack was shallow $(60 \mathrm{~cm}$ maximum depth, typically $30-40 \mathrm{~cm}$ ). Early in the season, the snow was very dry and porous with little cross linkage between crystals. As the season progressed, vapor diffusion along strong thermal gradients through the snowpack led to the development of a very porous depth hoar [Hardy et al., 1995], a type of microstructure characterized by large pore spaces with a high degree of vertical continuity. This structure was sustained into March, indicating the relative unimportance of processes such as wind drifting or the formation of melt-freeze crusts that could produce relatively impermeable layers. Melt features did not begin to develop until mid-March; by mid-April the snowpack had formed a thick $(5-10 \mathrm{~mm})$ melt-freeze crust. This crust was noticeably discontinuous around emergent plant stems and tree trunks.

Although late winter melt-freeze features may have oc- curred earlier during the warmer winter of 1994-1995, we do not believe that the snowpack was a significant barrier to $\mathrm{CO}_{2}$ transport from the soils for any prolonged periods. The seasonal evolution of snowpack features (such as depth hoar, ice structures, melt wells, and ablation rings around tree stems) assures an abundance of textural heterogeneities that maintain pathways through which transport can occur [Winston et al., 1995]. During the course of both winters during which we performed measurements, we did not observe the progressive seasonal accumulation of $\mathrm{CO}_{2}$ in the soil that would have indicated prolonged limitation of $\mathrm{CO}_{2}$ efflux to the atmosphere by restricted transport through the snowpack.

We suggest a similar conclusion regarding limitation of $\mathrm{CO}_{2}$ efflux by transport characteristics of the soil matrix. To support this conclusion, we can use our observed soil gas $\mathrm{CO}_{2}$ concentration versus depth gradients, with our measured $\mathrm{CO}_{2}$ fluxes, to calculate an apparent soil $\mathrm{CO}_{2}$ diffusivity consistent with an assumption that all $\mathrm{CO}_{2}$ production occurs at depths below those we use in the calculation. As a good test case, we used our data for February 1995 at OBS site 6A (Figure 4), where we believe (as argued above) that the soil $\mathrm{CO}_{2}$ concentration profile was influenced by restricted transport in the soil. We considered that diffusion between the depths of 30 and $25 \mathrm{~cm}$, where restricted transport is suggested, occurs through a homogeneous layer. We assumed, for simplification, that no $\mathrm{CO}_{2}$ production occurs in this layer and that we measured a flux at steady state described by Fick's first law:

$$
J=-D\left(d\left[\mathrm{CO}_{2}\right] / d z\right)
$$

where $J$ is the flux, $D$ is the effective diffusion coefficient for $\mathrm{CO}_{2}$ in the soil $\left(\mathrm{cm}^{3}\right.$ sorl arr $\mathrm{cm}^{-1}$ soll $\left.{ }^{-1}\right)$, and $d\left[\mathrm{CO}_{2}\right] / d z$ is the vertical concentration gradient ( $\mu$ mole $\mathrm{CO}_{2} \mathrm{~cm}^{-3}$ sor air $\left.\mathrm{cm}^{-1}{ }_{\text {soll }}\right)$. The time that it takes for a molecule to diffuse through the layer is given by [Bard and Faulkner, 1980]:

$$
t=d^{2} \theta / 2 D
$$

where $t$ is time, $d$ is the thickness of the diffusion layer, $\theta$ is the soil air content $\left(\mathrm{cm}^{3}\right.$ soil an $\mathrm{cm}^{-3}$ soil $)$, and $D$ is the effective diffusion coefficient obtained in equation (2). We calculated $D$ for this 30-25 cm layer of $6.31 \times 10^{-4} \mathrm{~cm}^{3}$ soll arr $\mathrm{cm}^{-1}{ }_{\text {sol }} \mathrm{s}^{-1}$ (using the data from January 24,1995 , flux $=0.17 \mu$ mole $\mathrm{C} \mathrm{m}^{2}$ $\mathrm{s}^{-1}$ ). The time required for a molecule to move through the layer ( $5 \mathrm{~cm}$ thick) is approximately 2.1 hours (using $\theta=$ growing season estimate of $0.38 \mathrm{~cm}^{3}$ soil arr $\mathrm{cm}^{-3}$ soil). This transit time suggests that even in a case where the soil gas $\mathrm{CO}_{2}$ profile suggests restricted transport, any effect of transport restriction on the flux of $\mathrm{CO}_{2}$ through the soil should not last more than a few hours. We therefore conclude that our measured fluxes represent ongoing production rather than release of previously produced $\mathrm{CO}_{2}$ that was retained due to restricted soil transport.

\section{$\mathrm{CO}_{2}$ Fluxes and Soil Temperatures}

Daily average soil $\mathrm{CO}_{2}$ fluxes for both winters are shown for all of the sites in Figure 5. The data show a seasonal decline from values generally higher than $0.8 \mu$ mole $\mathrm{m}^{2} \mathrm{~s}^{-1}$ in the fall, reaching minimum values of approximately $0.1-0.3 \mu$ mole $\mathrm{m}^{2}$ $\mathrm{s}^{-1}$ in February and increasing to higher but very scattered values in the spring. The daily averaged flux measurements generally agreed within $50 \%$ from site to site, and we could not infer any systematic differences from site to site. The interannual comparison in Figure 5 shows approximately similar flux 


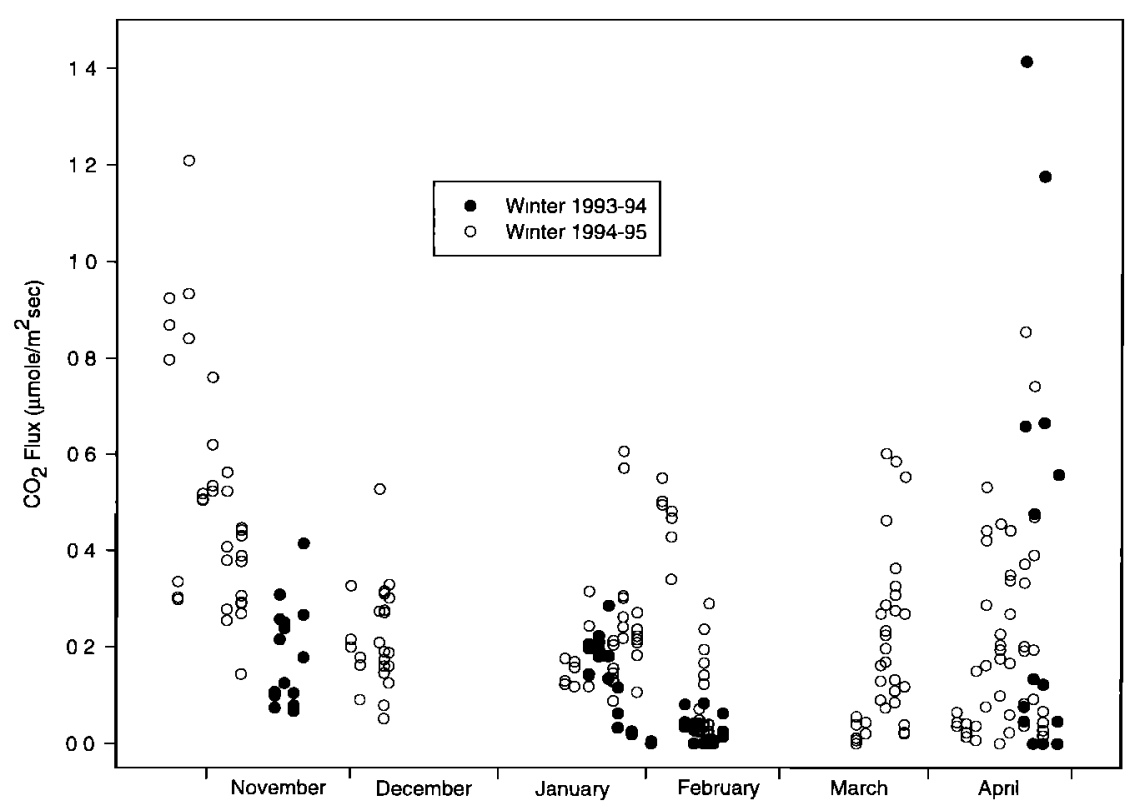

Figure 5. Winter $\mathrm{CO}_{2}$ fluxes measured at all sites during the winters of 1993-1994 and 1994-1995. Closed symbols are for 1993-1994 and open symbols are for 1994-1995.

magnitudes in early winter through January of both years. However, in February 1994 the fluxes dropped very close to zero, while many of the February 1995 measurements increased from January 1995 values. In late April of both years we observed a broader range of values than at other times. We believe that the broad range found in our early spring flux measurements may be due to the development of textural features within the snowpack, which enhance transport along "preferred" channels [Winston et al., 1995], and to spatial heterogeneities in the onset of shallow soil $\mathrm{CO}_{2}$ production associated with the spring thaw.

Figure 6 shows fluxes measured in 1994-1995 at OJP, OBS, and YJP plotted with soil temperatures for those sites. The fluxes generally appear to follow changes in the soil temperatures. A similar general relationship was shown previously for data from the same sites in the winter of 1993-1994 [Winston et al., 1995]. Using the Marquardt-Levenberg algorithm [Fox and Shotton, 1995], we fit the fluxes and temperatures from both winters to the equation of Lloyd and Taylor [1994]:

$$
\text { flux }=A\left(\exp \left(-E_{0} /\left(T-T_{0}\right)\right)\right.
$$

where flux is the average of our daily flux measurements at each site, $A$ is a normalizing variable determined in the fitting procedure, $E_{0}=308.56 \mathrm{~K}, T_{0}=227.13 \mathrm{~K}$, and $T$ is the shallowest soil absolute temperature measured at each site (see Figure 1). $E_{0}$ and $T_{0}$ are parameters derived by Lloyd and Taylor [1994] from a compilation of previously published studies relating soil respiration to temperature at many locations worldwide. The form of equation (4) was suggested by Lloyd and Taylor to best accommodate soil respiration rates over a wide range of temperatures. With the exception of the 1993 1994 data at the YJP site (where we measured anomalously low fluxes in November, possibly because they were obtained over a thin snowpack that had not yet covered the brushy understory), we found that the agreement between our data and equation (4) was very good for measurements taken during the periods when the soil temperatures were dropping (Figure
7). The fit of our data to equation (4) was poor for measurements taken during the periods after soil temperatures reached the seasonal minima and started to increase.

Soil respiration includes contributions from both plant roots and soil organisms and represents production from different depths and sources within the soil profile. Many studies have emphasized a positive correlation between soil respiration and shallow soil temperatures [e.g., Lloyd and Taylor, 1994]. The seasonal changes found in deeper soil temperatures generally follow those of shallow measurements. Thus a correlation between shallow soil temperature and soil respiration does not necessarily imply a shallow $\mathrm{CO}_{2}$ source. Likewise, deep soil respiration can support a temperature correlation even when shallow temperatures are below the minimum thought to be necessary for detectable biological activity.

Our data contain evidence supporting the idea that $\mathrm{CO}_{2}$ production is maintained in deep soil horizons where soil temperatures are relatively warm. February 1994 was the only period during which we measured deep $(>50 \mathrm{~cm})$ soil temperatures approaching or going below $-5^{\circ} \mathrm{C}$ (Figure 1). This was also the only period when our measured fluxes dropped very close to zero. Our data may suggest that $\mathrm{CO}_{2}$ production is maintained at depth until soil temperatures at that depth drop below the minimum temperature for measurable respiration. Any flux observed at the soil surface in midwinter is likely generated from depths where warmer temperatures are maintained. We believe that the seasonal decrease in winter fluxes is the result of production progressively decreasing in the upper soil horizons as cold temperatures propagate downward from the soil surface.

Our data obtained during warming periods could not be fit to equation (4) with the same parameters or goodness of fit found when the soils were cooling. This hysteretic relationship between soil temperatures and respiration indicates that the plant or microbial processes responsible for $\mathrm{CO}_{2}$ production when soils begin to warm are not the same as those occurring as soils cool near the lower temperature limit for respiration. 


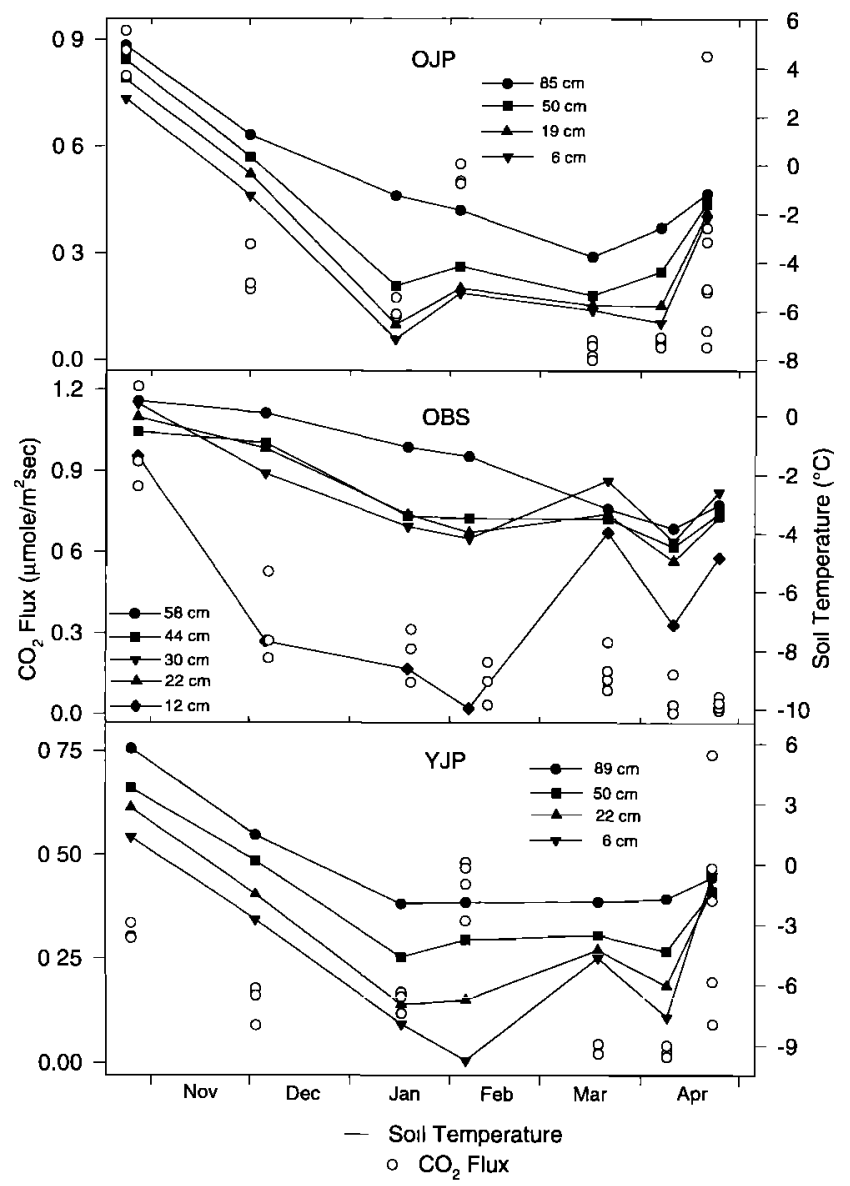

Figure 6. Soil temperatures (solid symbols) and $\mathrm{CO}_{2}$ fluxes (open symbols) measured at individual sites during the winter of 1994-1995. Sites and depths are as described for Figure 1.

We were unable to find previous evidence in the literature for the hypothesized hysteretic behavior of soil respiration at these temperatures. However, Skogland et al. [1988] found that a sudden increase in respiration occurs immediately after thawing frozen soil bacteria. They suggested that this phenomenon may have resulted from an increased nutrient supply (released from killed bacteria) or altered microenvironments causing rapid growth. Skogland et al. demonstrated different rates of $\mathrm{CO}_{2}$ production at the same temperature before freezing and after thawing. These experimental results lend support to our observations of a hysteretic response at low temperatures.

Further support for a hysteretic temperature dependence may be found in the transient midwinter warming event in 1995. Although soil temperatures remained below $0^{\circ} \mathrm{C}$ at all monitored depths, we observed a significant increase in measured fluxes in February 1995 at OJP and YJP (Figure 6). This increase coincided with a small increase in the temperatures of the upper soil horizons and may be evidence for a phenomenon similar to that observed by Skogland et al. Our observations during the midwinter 1995 warming event suggest that the hysteretic effects observed by Skogland et al. may extend to the flux-temperature relationship at subfreezing temperatures. These effects could explain why the flux-temperature relationship described by equation (4) could be fit only to the data for measurements obtained while the soil temperatures were decreasing.

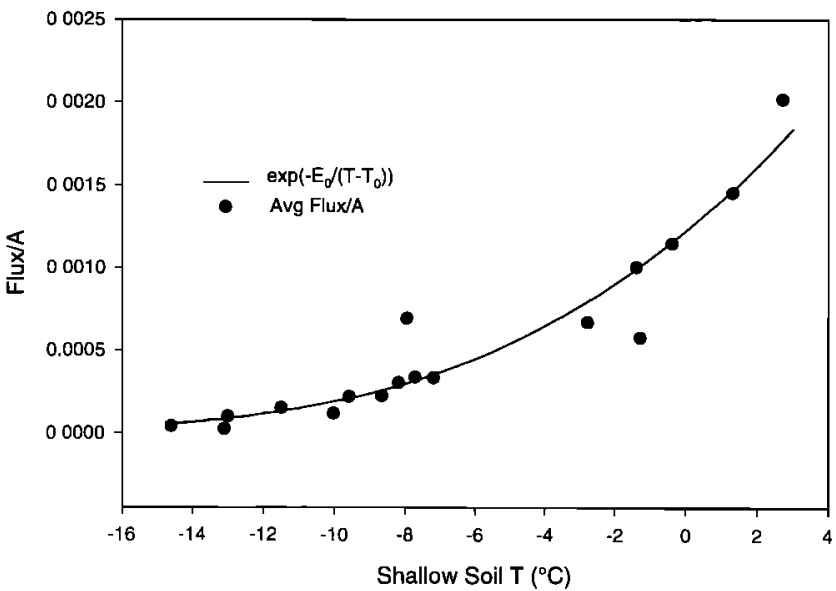

Figure 7. Normalized averaged soil fluxes versus shallow soil temperatures for the sites (excluding YJP 1993-1994) sampled both winters obtained when the soils were cooling. The solid line is the theoretical relationship of Lloyd and Taylor [1994].

\section{$\mathrm{CO}_{2}$ Fluxes and Soil Moisture Levels}

The role of soil moisture in winter $\mathrm{CO}_{2}$ production remains unclear. However, we believe that the evidence favors a stronger dependence of winter soil respiration on temperatures than on soil moisture. Our early winter measurements of $\varepsilon_{\text {app }}$ and $\mathrm{CO}_{2}$ fluxes might be viewed as supporting a positive correlation between soil moisture and respiration. However, this correlation is contradicted by the observation of generally higher $\mathrm{CO}_{2}$ fluxes in the winter of 1994-1995 than during 1993-1994, when soil moisture was apparently higher but temperatures were cooler. Moreover, during the February 1995 warming event discussed above, the fluxes appeared to follow changes in soil temperatures when the apparent dielectric constants remain relatively stable (Figure 2). In February 1994, when the deep soil temperatures dropped near or below $-5^{\circ} \mathrm{C}$ and fluxes neared zero, only slight changes (corresponding, according to equation (1), to a maximum loss of $1 \%$ volumetric soil moisture as liquid water) were observed in $\varepsilon_{\text {app }}$ for the clay soils. At depths of $40-60 \mathrm{~cm}$ in the clay soils, the calculated liquid water volumetric soil moisture remained above $20 \%$, a value not believed to be limiting for decomposition [Flanagan and Bunnell, 1980]. These observations suggest that interannual differences in measured $\mathrm{CO}_{2}$ fluxes, the suppression of respiration in February 1994, and the transient enhancement of respiration in February 1995, were all responding primarily to soil temperatures rather than moisture levels.

\section{Cumulative Winter $\mathrm{CO}_{2}$ Production}

Our data in 1993-1994 were not sufficient to estimate cumulative seasonal $\mathrm{CO}_{2}$ fluxes because of inadequate coverage during the transitions from fall into winter and from winter into spring. In 1994-1995 we made more measurements during these periods so that we could better characterize these transitions and calculate the cumulative production of $\mathrm{CO}_{2}$ by soils in winter. An estimate of daily production was made by averaging all of our flux measurements for each day that we performed them. To roughly approximate fluxes on days we did not perform measurements, we used a simple linear interpolation between our daily averages. Integrating these values over the dates shown in Figure 5 (October 27, 1994 to April 24, 1995 ) shows that approximately $40-55 \mathrm{gC} / \mathrm{m}^{2}$ were returned to 
Table 1. $\Delta^{14} \mathrm{C}$ of the Soil $\mathrm{CO}_{2}$

\begin{tabular}{lclcr}
\hline Site & $\begin{array}{c}\text { Depth, } \\
\text { cm }\end{array}$ & \multicolumn{1}{c}{ Date } & $\Delta^{14} \mathrm{C} \mathrm{CO}_{2}$ & $\Delta^{14} \mathrm{C}$ Source \\
\hline OJP & 85 & $11 / 14 / 93$ & 140.0 & 141.4 \\
OJP & 85 & $1 / 22 / 94$ & 100.0 & 96.1 \\
OJP & 85 & $4 / 22 / 94$ & 120.3 & 119.0 \\
OJP & 85 & $8 / 14 / 94$ & 136.1 & 136.4 \\
OJP & 85 & $10 / 30 / 94$ & 116.3 & 115.6 \\
OJP & 85 & $1 / 14 / 95$ & 75.0 & 52.9 \\
OJP & 85 & $2 / 8 / 95$ & 90.7 & 71.5 \\
OJP & 85 & $4 / 6 / 95$ & 99.9 & 87.1 \\
YJP & 92 & $11 / 14 / 93$ & 90.0 & 82.8 \\
YJP & 92 & $1 / 22 / 94$ & 116.0 & 43.6 \\
YJP & 92 & $4 / 22 / 94$ & 100.8 & 96.8 \\
YJP & 92 & $8 / 14 / 94$ & 135.1 & 135.5 \\
YJP & 92 & $10 / 30 / 94$ & 84.0 & 64.5 \\
YJP & 92 & $1 / 16 / 95$ & 31.2 & -289.2 \\
YJP & 92 & $2 / 10 / 95$ & 57.6 & -208.1 \\
YJP & 92 & $4 / 7 / 95$ & 57.3 & -70.3 \\
OBS & 48 & $11 / 14 / 93$ & 7.0 & -11.7 \\
OBS & 48 & $1 / 22 / 94$ & 57.0 & -101.9 \\
OBS & 48 & $4 / 22 / 94$ & 122.8 & 119.8 \\
OBS & 22 & $8 / 14 / 94$ & 140.9 & 145.2 \\
OBS & 22 & $10 / 30 / 94$ & 8.4 & -86.0 \\
OBS & 22 & $1 / 18 / 95$ & 70.7 & -152.2 \\
OBS & 22 & $4 / 12 / 95$ & 125.7 & 135.3 \\
\hline
\end{tabular}

OJP, old jack pine; YJP, young jack pine; OBS, old black spruce. Read 11/14/93 as November 14, 1993.

the atmosphere from the sites in this study during the winter of 1994-1995 (this range reflects the uncertainty in our interpolation and our underestimation of the true flux inherent in our closed-chamber measurements). As discussed above, this production originates from both plants and soil organisms. In calculating the contribution of winter $\mathrm{CO}_{2}$ production to annual carbon budgets, it is important to understand what sources are contributing to the soil efflux. We used ${ }^{14} \mathrm{C}$ measurements to examine the source of winter $\mathrm{CO}_{2}$ production.

\section{Carbon 14 Measurements}

Interpretation of our ${ }^{14} \mathrm{C}$ measurements requires an understanding of the recent history of ${ }^{14} \mathrm{C}$ in atmospheric $\mathrm{CO}_{2}$. In 1993-1994 the atmospheric $\Delta^{14} \mathrm{C}$ value was between +120 and +130 per mil. The $\Delta^{14} \mathrm{C}$ values greater than zero reflect the presence of ${ }^{14} \mathrm{C}$ produced in the late $1950 \mathrm{~s}$ and early $1960 \mathrm{~s}$ by atmospheric nuclear weapons testing ("bomb" ${ }^{14} \mathrm{C}$ ). The $\Delta^{14} \mathrm{C}$ of atmospheric $\mathrm{CO}_{2}$ peaked in the northern hemisphere in 1963-1964 at values close to +900 per mil and subsequently decreased as ${ }^{14} \mathrm{CO}_{2}$ exchanged with oceanic and biospheric $\mathrm{C}$ reservoirs. The $\Delta^{14} \mathrm{C}$ of atmospheric $\mathrm{CO}_{2}$ is presently decreasing at a rate of about 7 to 8 per mil per year [Levin et al., 1995]. Values of $\Delta^{14} \mathrm{C}$ less than zero indicate ${ }^{14} \mathrm{C}$ originally fixed from the atmosphere long enough ago for significant radioactive decay of ${ }^{14} \mathrm{C}$ (more than several hundred years).

We sampled soil $\mathrm{CO}_{2}$ from our deepest open gas probes several times each winter. The measured $\Delta^{14} \mathrm{C}$ of the soil gas $\mathrm{CO}_{2}$ for both winters is shown in Table 1 . The soil gas $\mathrm{CO}_{2}$ in winter is generally depleted in ${ }^{14} \mathrm{C}$ relative to modern atmospheric values. Samples taken from the same depths in August had $\Delta^{14} \mathrm{C}$ values near modern atmospheric values.

The isotopic composition of a mixture of components having different isotopic compositions can be found using the equation [Coplen, 1992]

$$
\delta_{1} N_{1}+\delta_{2} N_{2}+\delta_{3} N_{3} \cdots=\delta_{f}\left(N_{1}+N_{2}+N_{3} \cdots\right)
$$

where $\delta_{1}$ is the $\delta$ (or in this case $\Delta$ ) value of component $1, N_{1}$ is the number of atoms of component 1 , and $\delta_{f}$ is the $\delta$ (or in this case $\Delta$ ) value of the mixture. If we assume that each soil $\mathrm{CO}_{2}$ sample is produced by mixing two components, a single soil "source" and the atmosphere, we can solve equation (5) for the isotopic composition of the "source" given only the concentrations and isotopic compositions of the atmosphere and the sample. In reality, the calculated "source" $\Delta{ }^{14} \mathrm{C}$ represents a mass weighted average of soil $\mathrm{CO}_{2}$ sources. Our calculations (Table 1) show that this weighted average source is significantly older in the winter than in the summer.

It is unlikely that the $\mathrm{CO}_{2}$ sampled from our deep probes could have been produced by contemporary plants during the winter. Carbon dioxide, originating from plant respiration or from the decomposition of recently produced litter, would be expected to have modern values for $\Delta^{14} \mathrm{C}$ (as we observed in the summer, when plants are expected to be most active). Trumbore and Harden [this issue] have shown that the $\Delta^{14} \mathrm{C}$ values for organic soil carbon at our sites are more depleted with increasing soil depth. A carbonate origin for the depleted $\Delta^{14} \mathrm{C}$ values is ruled out by the $\delta^{13} \mathrm{C}$ values obtained for our gas samples, which ranged from -17 to -25 per mil. Thus the depleted $\Delta^{14} \mathrm{C}$ values of the winter soil $\mathrm{CO}_{2}$ are consistent with the decomposition of older sources at depth.

During the coldest periods of the winter we believe that our measured $\mathrm{CO}_{2}$ fluxes are maintained primarily by the production of $\mathrm{CO}_{2}$ originating from the decomposition of older carbon at depth. This conclusion is supported by the mixing curves shown in Figure 8. The most linear curves are obtained during the periods when soil temperatures are lowest, suggesting that the curves from those times effectively represent mixing between the atmosphere and a source of older carbon at depth.

Our ${ }^{14} \mathrm{C}$ measurements imply that the winter soil $\mathrm{CO}_{2}$ efflux cannot be simply the return to the atmosphere of carbon fixed during the previous growing season. A significant fraction of the winter soil respiration originates from the decomposition of old carbon stored at depth in the soil. This decomposition should be considered in annual carbon budget calculations. Moreover, our flux and temperature measurements suggest that this winter decomposition may be sensitive to interannual temperature fluctuations.

\section{Summary}

We have observed continuous $\mathrm{CO}_{2}$ fluxes produced in the soil throughout the winter in three ecotypes of a boreal forest. The fluxes reached minimum values in midwinter and appeared to follow general trends in soil temperatures. Fluxes observed during periods when the soils were cooling appeared to follow an exponential temperature dependence consistent with relationships observed in warmer regions. However, fluxes observed during periods of soil warming did not follow the same relationship. We hypothesize that near the lowertemperature limits for detectable soil respiration, $\mathrm{CO}_{2}$ production may exhibit a hysteretic response to soil temperature. This hysteresis may indicate that the processes responsible for $\mathrm{CO}_{2}$ production when soils first begin seasonal warming are different from those that predominate when soils are cooling.

After the initial freezing of soil water, fluxes were seen to change independently of soil moisture. The fluxes appeared to follow changes in soil temperatures when the apparent dielectric constants remained relatively stable, suggesting that $\mathrm{CO}_{2}$ production was responding primarily to soil temperatures rather than moisture levels. 


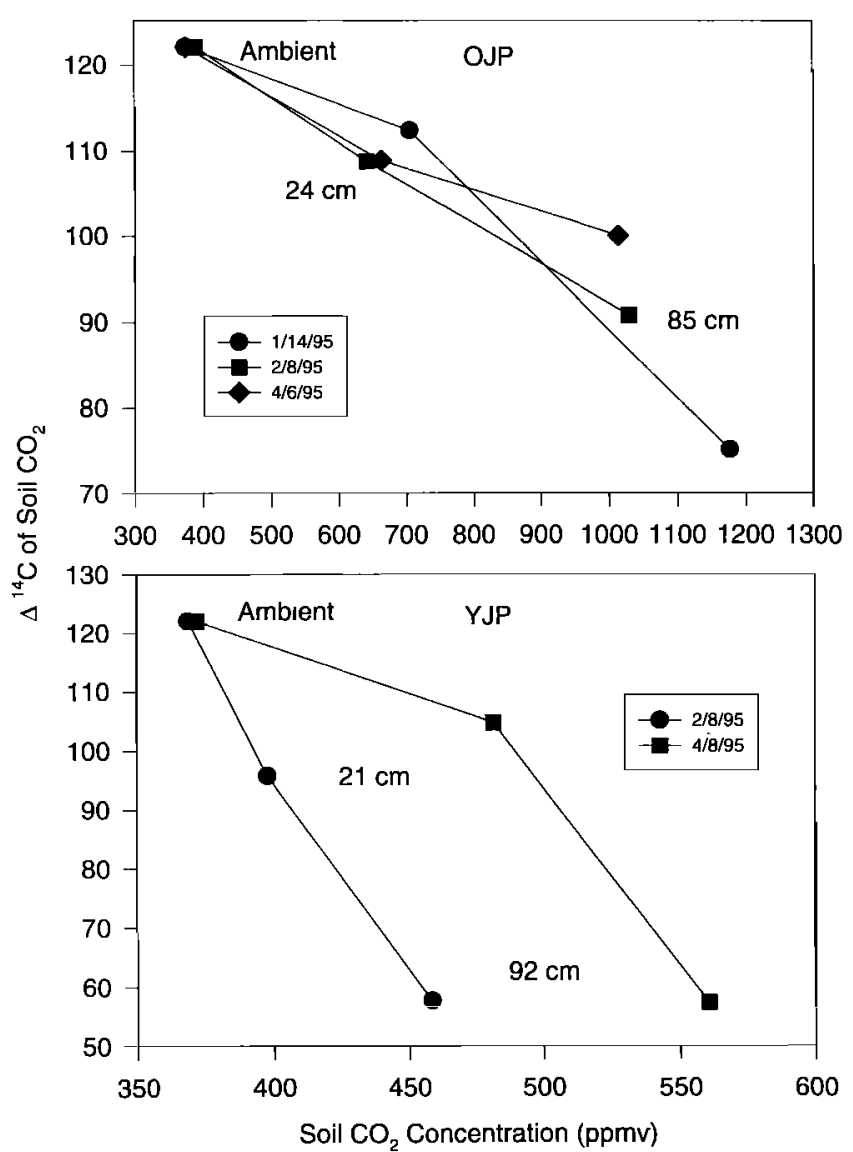

Figure 8. $\Delta^{14} \mathrm{C}$ mixing curves obtained from YJP and OJP during the winter of 1994-1995.

On the basis of diffusivities calculated from our measured $\mathrm{CO}_{2}$ concentrations in soil gas, $\mathrm{CO}_{2}$ fluxes, and assumed soil air contents, we conclude that our measured fluxes represented ongoing production rather than the release of $\mathrm{CO}_{2}$ produced during the growing season. This production amounted to the cumulative release to the atmosphere of approximately $40-55$ $\mathrm{gC} / \mathrm{m}^{2}$ from the soils of our study sites between November 1994 and April 1995. Analysis of $\Delta^{14} \mathrm{C}$ of soil $\mathrm{CO}_{2}$ showed that the soil $\mathrm{CO}_{2}$ was much older in winter than during the growing season. We conclude that the soil $\mathrm{CO}_{2}$ originated from an old source of carbon found at depths in the soil which were warm enough to maintain decomposition. The winter decomposition of deep, old soil carbon should be included in the accounting for carbon budgets over a wide range of timescales. A persistent interannual trend toward warmer winters may be expected to enhance the contribution of this source to annual $\mathrm{CO}_{2}$ budgets for the boreal forest.

Acknowledgments. This paper is dedicated to Professor Paul Louis Goodfriend "A gentleman, scholar, and lover of good "um ... conversation'." The authors gratefully acknowledge the helpful review comments of Paul Brooks, Patrick Crill, Bert Davis, Alisa Mast, and Nigel Roulet. We would like to thank the U.S. Geological Survey and NASA for funding used in this research. Also, the assistance of Jennifer Harden, Molly Bentley, Kathy O'Neill, Tom Black, Patrick Crill, Nigel Roulet, and Tim Moore in site preparation and the loan of equipment is greatly appreciated. Finally, our gratitude goes to the hospitable people of Thompson, Manitoba, and especially INCO for providing free and warm laboratory space.

\section{References}

Albert, M. R., and J. P. Hardy, Ventilation experiments in seasonal snow cover, in Blogeochemistry of Seasonally Snow-Covered Catchments, edited by K. Tonnessen, M. W. Williams, and M. Trantor, LAHS Publ. 228, pp. 41-50, 1995.

Bard, A. J., and L. R. Faulkner, Electrochemical Methods, John Wiley, New York, 1980.

Bauer, J., P. M. Williams, and E. R. M. Druffel, Recovery of submilligram quantities of carbon dioxide from gas streams by molecular sieve for subsequent determination of isotopic natural abundance, Anal. Chem., 64, 824-827, 1992.

Benoit, R. E., W. B. Campbell, and R. W. Harris, Decomposition of organic matter in the wet meadow tundra, Barrow: A Revised word model, in Proceedings of the 1972 Tundra Biome Symposium at Lake Wilderness Center, Univ, of Wash., coordinated by J. Brown, pp. 111-115, Tundra Biome Cent., Univ. of Alaska, Fairbanks, 1972.

Brooks, P. D., M. W. Williams, and S. K. Schmidt, Microbial actıvity under alpine snowpacks, Niwot Ridge, Colorado, Blogeochemustry, 32, 93-113, 1996.

Carreiro, M. M., and R. E. Koske, Effect of temperature on decomposition and development of microfungal communities in leaf litter microcosms, Can J. Bot., 70, 2177-2183, 1992.

Coplen, T. B., Uses of environmental isotopes, in Regional GroundWater Quality, edited by W. Alley, Van Nostrand Reinhold, New York, 1992.

Coxson, D. S., and D. Parkinson, The pattern of winter respiratory response to temperature, moisture, and freeze-thaw exposure in Bouteloua Gracilus dominated grassland soils of southwestern Alberta, Can. J. Bot., 65, 1716-1725, 1987a.

Coxson, D. S., and D. Parkınson, Wınter respiratory activity in aspen woodland forest floor litter and soils, Soll Biol. Biochem., 19(1), $49-59,1987 \mathrm{~b}$.

Coyne, P. I., and J. J. Kelley, Variations in carbon dioxide across an Arctic snowpack during spring, J. Geophys. Res., 79(6), 799-802, 1974.

Davidson, E. A., and S. E. Trumbore, Gas diffusivity and production of $\mathrm{CO}_{2}$ in deep soils of the eastern Amazon, Tellus, 47(B), 550-565, 1995.

Dorr, $\mathrm{H}$., and K. O. Munnich, Annual variation in soil respiration in selected areas of the temperate zone, Tellus, 39(B), 114-121, 1987.

Edwards, N. T., Effects of temperature on carbon dioxide evolution in a mixed deciduous forest floor, Soil Sci. Soc. Am. Proc., 39, 361-365, 1975.

Flanagan, P. W., and F. L. Bunnell, Microflora activities and decomposition, An Arctic Ecosystem: The Coastal Tundra at Barrow, Alaska, edited by J. Brown, P. C. Miller, L. L. Tieszen, and F. L. Bunnell, pp. 291-334, Van Nostrand Reinhold, New York, 1980.

Flanagan, P. W., and A. Scarborough, Laboratory and field studies on decomposition of plant material in Alaskan tundra areas, in Proceedings of the 1972 Tundra Biome Symposium at Lake Wilderness Center, Unıv. of Wash., coordinated by J. Brown, 110 pp., Tundra Biome Cent., Univ. of Alaska, Fairbanks, 1972.

Flanagan, P. W., and A. K. Veum, Relationships between respiration, weight loss, temperature and moisture in organic residues on tundra, in Soil Organisms and Decomposition in Tundra, edited by A. J. Holding, W. O. Heal, S. F. MacLean Jr., and P. W. Flanagan, pp. 249-277, IBP Steering Committee, Stockholm, 1974.

Fox, E., and K. Shotton, Transforms and Nonlinear Regressions, Jandel Sci., San Rafael, Calif., 1995.

Frolking, S., et al., Modeling temporal variability in the carbon balance of a spruce/moss boreal forest, Global Change Biology, 1996.

Goulden, M. L., B. C. Daube, S. M. Fan, D. J. Sutton, A. Bazzaz, J. W. Munger, and S. C. Wofsy, Physiological responses of a black spruce forest to weather, $J$. Geophys. Res., this issue.

Hardy, J. P., R. E. Davis, and G. C. Winston, Evolution of factors affecting gas transmissivity of snow in the boreal forest, in Biogeochemustry of Seasonally Snow-Covered Catchments, edited by K. Tonnessen, M. W. Williams, and M. Trantor, LAHS Publ. 228, pp. 51-59, 1995.

Havas, P., and E. Määenpàa, Evolution of carbon dioxide at the floor of a Hylocomium Myrtillus type spruce forest, Aquilo Ser. Bot., 11, 4-22, 1972.

Levin, I., R. Graul, and N. B. A. Trivett, Long-term observations of atmospheric $\mathrm{CO}_{2}$ and carbon isotopes at continental sites in Germany, Tellus, B47, 23-34, 1995. 
Lloyd, J., and J. A. Taylor, On the temperature dependence of soil respiration, Funct. Ecol., 8, 315-323, 1994.

Massman, W., R. Sommerfeld, K. Zeller, T. Hehn, L. Hudnell, and S. Rochelle, $\mathrm{CO}_{2}$ flux through a Wyoming seasonal snowpack: Diffusional and pressure pumping effects, in Biogeochemistry of Seasonally Snow-Covered Catchments, edited by K. Tonnessen, M. W. Williams, and M. Trantor, $L A H S$ Publ. 228, pp. 71-80, 1995.

O'Neill, K., J. W. Harden, S. E. Trumbore, M. O. Bentley, G. Winston, B. B. Stephens, and T. A. Black, Boreal Ecosystem-Atmosphere Study (BOREAS) 1993 field notes, Thompson, Manitoba, U.S. Geol. Surv. Open-File Rep. 94-488, 1994a.

O'Neill, K., J. W. Harden, S. E. Trumbore, M. O. Bentley, G. Winston, B. B. Stephens, and T. A. Black, Boreal Ecosystem-Atmosphere Study (BOREAS) 1993 laboratory data, Thompson, Manitoba, U.S. Geol. Surv. Open-Fule Rep. 94-489, $1994 \mathrm{~b}$.

Patterson, D. E., and M. W. Smith, The measurement of unfrozen water content by time domain reflectometry: Results from laboratory tests, Can. Geotechnol. J., 18, 131-144, 1981.

Phillipson, J., R. J. Putman, J. Steel, and S. R. J. Woodell, Litter Input, Litter decomposition and the evolution of carbon dioxide in a beech woodland-Wytham Woods, Oxford, Oecologia, 20, 203-217, 1975.

Schimel, J. P., K. Kielland, and F. S. Chapin III, Nutrient availability and uptake by tundra plants, in Landscape Function: Implications for Ecosystem Response to Disturbance; a Case Study in Arctic Tundra, edited by J. F. Reynolds and J. D. Tenhunen, Springer-Verlag, New York, 1995.

Skogland, T., S. Lomeland, and J. Goksoyr, Respiratory burst after freezing and thawing of soil: Experiments with soil bacteria, Soil Biol. Biochem., 20(6), 851-856, 1988.

Solomon, D. K., and T. E. Cerling, The annual carbon dioxide cycle in a montane soil: Observations, modeling, and implications for weathering, Water Resour. Res., 23(12), 2257-1165, 1987.

Sommerfeld, R. A., R. C. Musselman, J. O. Reuss, and A. R. Mosier, Preliminary measurements of $\mathrm{CO}_{2}$ in melting snow, Geophys. Res. Lett., 18(7), 1225-1228, 1991.

Sommerfeld, R. A., A. R. Mosier, and R. C. Musselman, $\mathrm{CO}_{2}, \mathrm{CH}_{4}$, and $\mathrm{N}_{2} \mathrm{O}$ flux through a Wyoming snowpack and implications for global budgets, Nature, 361, 140-142, 1993.

Sommerfeld, R. A., W. J. Massman, and R. C. Musselman, Diffusional flux of $\mathrm{CO}_{2}$ through snow: Spatial and temporal variability among alpine-subalpine sites, Global Biochem. Cycles, 10(3), 473-482, 1996.

Southon, J. R., J. S. Vogel, S. E. Trumbore, J. C. Davis, and others, Progress in AMS measurements at the LLNL spectrometer, Radiocarbon, 34, 473-477, 1992.

Stephens, B. B., and E. T. Sundquist, Measurement of soil surface gas fluxes using closed chamber techniques: Are they accurate and scal- able? (abstract), EOS Trans. AGU, Fall Meet. Suppl., 76(46), 223224, 1995.

Stuiver, M., and H. Polach, Reporting of ${ }^{14} \mathrm{C}$ data, Radiocarbon, 19 , 355-363, 1977.

Sturm, M., and J. B. Johnson, Natural convection in the subarctic snow cover, J. Geophys. Res., 96, 11,657-11,671, 1991.

Taylor, B. R., and H. G. Jones, Litter decomposition under snow cover in a balsam fir forest, Can. J. Bot., 68, 112-120, 1990.

Topp, G. C., J. L. Davis, and A. P. Annan, Electromagnetic determination of soil water content: Measurement in coaxial transmission lines, Water Resour. Res., 16(3), 574-582, 1980.

Trumbore, S. E., and J. Harden, Input, accumulation, and turnover of carbon in soils of the BOREAS northern study area, J. Geophys. Res., this issue.

Vuorinen, M., and T. Kurkela, Concentration of $\mathrm{CO}_{2}$ under snow cover and the winter activity of the snow blight fungus phacidium infestans, Eur. J. For. Path., 23, 441-447, 1993.

Winston, G. C., E. T. Sundquist, and A. B. Shortlidge, $\mathrm{CO}_{2}$ fluxes through the snowpack at Sleepers River, Vermont, Eos Trans. $A G U$, 73(43), 174, 1992.

Winston, G. C., B. B. Stephens, E. T. Sundquist, J. P. Hardy, and R. E. Davis, Seasonal variability in $\mathrm{CO}_{2}$ transport through snow in a boreal forest, in Biogeochemistry of Seasonally Snow-Covered Catchments, edited by K. Tonnessen, M. W. Williams, and M. Trantor, LAHS Publ. 228, pp. 61-70, 1995.

Woodwell, G. M., and W. R. Dykeman, Respiration of a forest measured by carbon dioxide accumulation during temperature inversions, Science, 154, 1031-1034, 1966.

Zimov, S. A., G. M. Zimova, S. P. Daviodov, A. I. Daviodova, Y. V. Voropaev, Z. V. Voropaeva, S. F. Prosiannikov, O. V. Prosiannikova, I. V. Semiletova, and I. P. Semiletov, Winter biotic activity and production of $\mathrm{CO}_{2}$ in Siberian soils: A factor in the greenhouse effect, J. Geophys. Res., 98, 5017-5023, 1993.

B. B. Stephens, Scripps Institution of Oceanography, University of California, San Diego, La Jolla, CA 92093-0208.

S. E. Trumbore, Earth System Science, University of California, Irvine, CA 92717.

E. T. Sundquist and G. C. Winston, U.S. Geological Survey, 384 Woods Hole Road, Woods Hole, MA 02543. (e-maıl: gwinston@usgs. gov)

(Received September 16, 1996; revised February 3, 1997; accepted March 3, 1997.) 